\title{
Effect of long working hours and insomnia on depressive symptoms among employees of Chinese internet companies
}

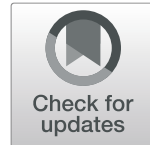

Xiaoman $\mathrm{Liu}^{1 \dagger}$, Chao Wang ${ }^{2 \dagger}$, Jin Wang ${ }^{1}$, Yuqing $\mathrm{Ji}^{1}$ and Shuang $\mathrm{Li}^{{ }^{*}}$

\begin{abstract}
Background: In China, long working hours and insomnia are relatively common among internet company employees. Considering that both can affect mental health, we examined their independent and interaction effects on these employees' depressive symptoms (DS).

Methods: We analyzed data from the 2016 occupational health questionnaire survey conducted in 35 large-, medium-, and small-scale internet companies. Overall, 3589 full-time employees were recruited to evaluate the association among working hours, insomnia, and DS. The Patient Health Questionnaire (PHQ-9) was used to assess DS. The association of DS (PHQ-9 $\geq 10)$ with working hours ( $\leq 40,41-50,51-60$, and $>60 \mathrm{~h} /$ week), insomnia (with or without), and interaction of both was estimated using multivariable logistic regression analysis.

Results: Compared with the group working for $\leq 40 \mathrm{~h} /$ week, the adjusted odds ratios (ORs) for DS among participants who worked for 41-50 h/week, 51-60 h/week, and > $60 \mathrm{~h} /$ week were 1.32 (1.11-1.56), 1.74 (1.35-2.24), and 2.54 (1.90-3.39), respectively. The ORs for DS among those with insomnia were 2.36 (2.04-2.74) after adjusting for general characteristics. The ORs for DS related to insomnia were similar [1.91 (1.46-2.50), 2.00 (1.61-2.50), respectively] in the participants who worked for $<50 \mathrm{~h} /$ week. However, among participants working for $51-60 \mathrm{~h}$ or $>60 \mathrm{~h} /$ week, the adjusted ORs for DS substantially increased to 4.62 (2.90-7.37) and 5.60 (3.36-9.33), respectively. Moreover, among the participants with insomnia, working overtime showed a greater association with DS.

Conclusions: We showed that long working hours and insomnia are independent factors associated with the prevalence of DS; furthermore, an interaction effect of long working hours and insomnia on DS was observed. For relieving DS in internet company employees, it is important to reduce insomnia.
\end{abstract}

Keywords: Long working hours, Insomnia, Depressive symptom, Interaction effect

\footnotetext{
* Correspondence: lishuang@niohp.chinacdc.cn

${ }^{\dagger}$ Xiaoman Liu and Chao Wang should be considered joint first authors.

'National Institute of Occupational Health and Poison Control, Chinese

Center for Disease Control and Prevention, 29 Nanwei Road, Xicheng District,

Beijing, P.R. China 100050

Full list of author information is available at the end of the article
}

(C) The Author(s). 2021 Open Access This article is licensed under a Creative Commons Attribution 4.0 International License, which permits use, sharing, adaptation, distribution and reproduction in any medium or format, as long as you give appropriate credit to the original author(s) and the source, provide a link to the Creative Commons licence, and indicate if changes were made. The images or other third party material in this article are included in the article's Creative Commons licence, unless indicated otherwise in a credit line to the material. If material is not included in the article's Creative Commons licence and your intended use is not permitted by statutory regulation or exceeds the permitted use, you will need to obtain permission directly from the copyright holder. To view a copy of this licence, visit http://creativecommons.org/licenses/by/4.0/ The Creative Commons Public Domain Dedication waiver (http://creativecommons.org/publicdomain/zero/1.0/) applies to the data made available in this article, unless otherwise stated in a credit line to the data. 


\section{Background}

Recently, the internet industry in China has undergone an explosive increase in discussions regarding the "996" work system (working hours: 9 am to 9 pm, 6 days per week). In 2019, for the first time, a large-scale universal discussion was conducted among Chinese internet company employees regarding overtime, overwork, and enterprise violation of labor contracts, and this discussion has had an international impact. The survival of the internet industry relies on continuous innovation, which is considered a matter of concern by these companies, thereby rendering long working hours a commonplace in Chinese internet companies $[1,2]$. However, extending working hours does not necessarily improve the efficiency and ability of employees; on the contrary, employees have little time to spend with and care for their family, which can lead to poorer work quality and declining work ability as well as a result in damage to their physical and mental health [3-5]. In recent years, European countries have been the focus of research on the adverse effects of long working hours, followed by East Asia, particularly Japan and South Korea. Research conducted in China on long working hours is limited; however, the working hours followed in China are among the longest in the world, overtime, overwork and even "karoshi" (death from overwork) are common among Chinese individuals [6]. Therefore, further attention is required regarding the adverse effects caused by long working hours in China.

Depression is one of the most common mental health disorders. It is one of the leading causes of disability worldwide and a major contributor to the overall global burden of disease [7]. In China, the lifetime prevalence of depression is approximately 6\% [8], and it is the fourth leading cause of disability [9]. Several factors contribute to depressive symptoms (DS); numerous studies have shown that working long hours is likely an important risk factor for DS [10-14]. A systematic review and meta-analysis involving approximately 190,000 participants from 28 prospective cohort studies in 35 countries reported that an increased risk of depression was linked to prior overtime work in Europe and, to a greater extent, in Asia [15]. The mechanisms linking long working hours and DS involved social support, high demand and low control, effort-reward imbalance, effort-recovery imbalance, and others [16-18]. Long working hours lead to sleep deprivation and lack of recovery from workrelated stress, thereby reducing non-working time, increasing injuries, and prolonging exposure to work needs and workplace hazards [19]. These direct consequences might develop into depression by fatigue; negative emotions owing to lack of time for socialization and life; and bad feelings toward work because of increased exposure to workplace demands and hazards [20].
Considering that long working hours are positively associated with insomnia, few studies have been conducted to illustrate the effects of their interaction on subsequent health issues, such as depressive disorder, because both interfere with the energy recovery and mental burnout of individuals. This hypothesis has been indicated by Nakata, who reported that the combination of long working hours and short sleep periods posed the strongest risk for DS among full-time employees [21]. Regarding associations between insomnia and depression, causation, i.e., the interacting effects of insomnia and working time on mental health, remain poorly understood. Insomnia is one of the most common sleep disorders. Studies have shown that approximately $70 \%$ of patients with depression have insomnia [22], and patients with insomnia without DS have a two-fold risk of developing depression compared with individuals without insomnia [23]. According to an epidemiological study, the prevalence rate of insomnia in Chinese adults was between 9.2 and $11.2 \%$ [24]. In 2016, the first survey on the sleep quality of Chinese internet company employees had found that approximately $80 \%$ of the individuals experienced poor sleep quality, $71.3 \%$ experienced insomnia, and $60 \%$ often worked overtime [25].

Therefore, the objective of the present study was to examine the effect of long working hours and insomnia on the DS of full-time employees using data from 35 large-, medium-, and small-scale internet companies in China. We hypothesized that long working hours and insomnia are both independent factors associated with the prevalence of DS among internet company employees and that there may be an interaction effect of long working hours and insomnia on DS.

\section{Methods \\ Study design and population}

The study used a cross-sectional design. From June to September 2016, employees from 35 large-, medium-, and small-scale internet companies were selected from Beijing, Shandong, and Zhejiang provinces. The enterprises selected were based on the broad internet enterprise classification, including basic, service, and terminal layer internet enterprises. In each enterprise, the anonymous self-administered questionnaire survey was employed, and it was distributed, guided, completed, and reviewed by the investigators after unified training. Auditors were assigned to review issues related to quality, such as missing items and logical contradictions. A total of 4355 participants with various job positions participated in the survey. The inclusion criteria for participants were as follows: employees who had worked in their current position for at least 6 months and who did not have any recent mental disease or are not on any 
psychotropic medication. Finally, 3589 qualified questionnaires were received, with an effective recovery rate of $82.41 \%$. The study was approved by the Medical Ethics Committee of the National Institute of Occupational Health and Poison Control. Each participant provided written informed consent.

\section{DS}

DS was measured using a Chinese version of the Patient Health Questionnaire (PHQ-9) [26]. The 9-item DS scale measures the frequency levels of DS experienced in the past 2 weeks. The 4 frequency levels are 0 (never), 1 (occasionally), 2 (more than half), and 3 (always). The PHQ-9 scale cut-off score is 10, which differentiates between those exhibiting high levels of DS (score $\geq 10$ ) and those with lower levels of such symptoms $($ score $<10$ ). PHQ-9 is a simple and effective instrument for making diagnoses and assessing the severity of depressive disorders, particularly in busy clinical practice settings [27].

\section{Number of working hours}

Working hours were determined by an open-ended question: for how many hours do you usually work in a week (including overtime)? According to the relevant provisions of the labor law and the regulations of the State Council on employees' working hours, the current standard working hour system in China is $8 \mathrm{~h} /$ day and $40 \mathrm{~h} /$ week $[28,29]$. Therefore, the number of working hours was grouped into 4 categories: $\leq 40,41-50,51-60$, and $>60 \mathrm{~h} /$ week.

\section{Insomnia}

Insomnia was determined using a Chinese version of the Sleep Questionnaire (Supplementary file 1), which was modified from Nakata's Self-administrated Sleep Questionnaire [30]. The questionnaire included 3 questions about subjective sleep habits during the last 1 year. Difficulty initiating sleep (DIS) was defined as requiring $>30$ min to fall asleep. Difficulty maintaining sleep (DMS) and early morning awakening (EMA) were defined by a response of ">3 times a week" to the second and third questions [31, 32]. The presence of insomnia was defined by at least 1 positive response to questions regarding DIS, DMS, or EMA.

\section{Covariates}

Demographic, socioeconomic, and health-related covariates were included in the present study. The covariates were age $(16-25,26-30,31-35,36-40$, or $\geq 41$ years), sex (male or female), education level (high school, junior college, college, or graduate school), marital status (married, single, divorced, or widowed), income $(¥)(\leq 4999$, $5000-7999$, 8000-11,999, or $\geq 12,000)$, exercise frequency (never, 1-3 times per month, 1-2 times per week or $\geq 3$ times per week), dietary habits (regular, occasional, irregular, often irregular, or totally irregular), and smoking status (nonsmoker, former smoker, or current smoker). Exercise frequency was measured using the question: "Do you perform any exercise?" Exercising for $>30 \mathrm{~min}$ was recommended for effective health promotion [33].

\section{Statistical analysis}

The chi-squared test was used to compare group differences in categorical data. The study hypotheses were analyzed based on logistic regression analysis to investigate the relationship among work time (WT), insomnia, and depression. The interaction effect of WT and insomnia on DS was investigated using stratified logistic regression analysis. For the analysis of the independent effects, WT and insomnia were first introduced into the regression simultaneously after adjusting for general characteristics, such as sex, age, education level, marital status, income, exercise frequency, dietary habits, and smoking status. The regression model then further introduced an interaction value of WT $\times$ insomnia to detect the interaction effect. The interaction value of WT in model 2 was introduced as a continuous variable. A $p$-value of $<0.05$ was considered to indicate statistical significance. All analyses were performed using IBM Statistics SPSS 22.0.

\section{Results}

\section{Characteristics of study participants}

Overall, 4355 questionnaires were issued in the survey and 3589 (82.41\%) completed questionnaires were eligible for the analysis. Among the entire sample, $56.3 \%$ of the participants were males, and the average age was $33 \pm 9$ years (range: $17-60$ years). Further, $56.0 \%$ of the participants received a college education, with $9.6 \%$ having only a high school background. Most participants (65.8\%) were married. Approximately $70 \%$ of the participants earned <¥8000/month. The chi-squared test showed that except for sex, most of the distribution of general characteristics between the DS groups was statistically significant $(p<0.05)$ (Table 1$)$. Participants who worked for $>60 \mathrm{~h} /$ week showed the highest rate of DS (48.3\%); $41.7 \%$ were classified to have insomnia, among which $53.7 \%$ had DS (Table 1).

\section{Analyses among WT, insomnia, and depression}

The majority of participants worked for $\leq 50 \mathrm{~h} /$ week, which accounted for $77.7 \%$ of the total participants. Those who worked for $>50 \mathrm{~h} /$ week reported a significantly higher rate of DS, particularly when they worked for $>60 \mathrm{~h} /$ week. Compared with the group working for $\leq 40 \mathrm{~h} /$ week, the odds ratios (ORs) for DS among those who worked for 41-50, 51-60, and $>60 \mathrm{~h} /$ week showed a gradual increase and adjusted ORs were 1.32 (1.11- 
Table 1 General characteristics and depressive symptoms

\begin{tabular}{|c|c|c|c|c|c|}
\hline \multirow[t]{2}{*}{ Characteristics } & & \multirow{2}{*}{$\begin{array}{l}\text { Total } \\
\mathrm{N}(\%)\end{array}$} & \multicolumn{3}{|c|}{ Depressive symptoms } \\
\hline & & & $\begin{array}{l}\text { Negative } \\
\mathrm{n}(\%)\end{array}$ & $\begin{array}{l}\text { Positive } \\
\mathrm{n}(\%)\end{array}$ & $p$-value \\
\hline Total & & $3589(100.0)$ & $2175(60.6)$ & $1414(39.4)$ & \\
\hline \multirow[t]{5}{*}{ Age group } & $16-25$ & $625(17.4)$ & $421(67.4)$ & $204(32.6)$ & $<0.001$ \\
\hline & $26-30$ & $954(26.6)$ & $665(69.7)$ & $289(30.3)$ & \\
\hline & $31-35$ & $753(21.0)$ & $478(63.5)$ & $275(36.5)$ & \\
\hline & $36-40$ & $507(14.1)$ & $275(54.2)$ & $232(45.8)$ & \\
\hline & $\geq 41$ & $750(20.9)$ & $387(51.6)$ & $363(48.4)$ & \\
\hline \multirow[t]{2}{*}{ Sex } & Male & $2022(56.3)$ & $1267(62.7)$ & $755(37.3)$ & 0.371 \\
\hline & Female & $1567(43.7)$ & $959(61.2)$ & $608(38.8)$ & \\
\hline \multirow[t]{4}{*}{ Education } & High school & $344(9.6)$ & $209(60.8)$ & $135(39.2)$ & $<0.001$ \\
\hline & Junior college & $521(14.5)$ & $280(53.7)$ & $241(46.3)$ & \\
\hline & College & $2009(56.0)$ & $1242(61.8)$ & $767(38.2)$ & \\
\hline & Graduate school & $715(19.9)$ & $495(69.2)$ & $220(30.8)$ & \\
\hline \multirow[t]{3}{*}{ Marital status } & Married & $2363(65.8)$ & $1401(59.3)$ & $962(40.7)$ & $<0.001$ \\
\hline & Single & 1159 (32.3) & $794(68.5)$ & $365(31.5)$ & \\
\hline & Separated/divorced/widowed & $67(1.9)$ & $31(46.3)$ & $36(53.7)$ & \\
\hline \multirow[t]{4}{*}{ Income(¥) } & $\leq 4999$ & 1319 (36.8) & $717(54.4)$ & $602(45.6)$ & $<0.001$ \\
\hline & 5000-7999 & 1105 (30.8) & $690(62.4)$ & $415(37.6)$ & \\
\hline & 8000-11,999 & $767(21.4)$ & 534 (69.6) & $233(30.4)$ & \\
\hline & $\geq 12,000$ & $398(11.1)$ & 285 (71.6) & $113(28.4)$ & \\
\hline \multirow[t]{4}{*}{ Exercise } & Never & $527(14.7)$ & $278(52.8)$ & $249(47.2)$ & $<0.001$ \\
\hline & $1-3$ times/month & $1626(45.3)$ & $1003(61.7)$ & $623(38.3)$ & \\
\hline & 1-2 times/week & $927(25.8)$ & $598(64.5)$ & $329(35.5)$ & \\
\hline & $\geq 3$ times / week & $509(14.2)$ & $347(68.2)$ & $162(31.8)$ & \\
\hline \multirow[t]{4}{*}{ Dietary habits } & Regular & $2069(57.6)$ & $1406(68.0)$ & $663(32.0)$ & $<0.001$ \\
\hline & Occasionally irregular & $968(27.0)$ & $579(59.8)$ & $389(40.2)$ & \\
\hline & Often irregular & $440(12.3)$ & $193(43.9)$ & $247(56.1)$ & \\
\hline & Totally irregular & $112(3.1)$ & $48(42.9)$ & $64(57.1)$ & \\
\hline \multirow[t]{3}{*}{ Smoking status } & Nonsmoker & $2701(75.3)$ & $1725(63.9)$ & $976(36.1)$ & $<0.001$ \\
\hline & Former smoker & $287(8.0)$ & $153(53.3)$ & $134(46.7)$ & \\
\hline & Current smoker & $601(16.7)$ & $348(57.9)$ & $253(42.1)$ & \\
\hline \multirow[t]{4}{*}{ Work time } & $\leq 40 \mathrm{~h} /$ week & $1147(32.0)$ & $752(65.6)$ & $395(34.4)$ & $<0.001$ \\
\hline & 41-50 h/week & $1641(45.7)$ & $982(59.8)$ & $659(40.2)$ & \\
\hline & 51-60 h/week & $420(11.7)$ & $244(58.1)$ & $176(41.9)$ & \\
\hline & $>60 \mathrm{~h} /$ week & $381(10.6)$ & $197(51.7)$ & $184(48.3)$ & \\
\hline \multirow[t]{2}{*}{ Insomnia } & Negative & $2091(58.3)$ & $1481(70.8)$ & $610(29.2)$ & $<0.001$ \\
\hline & Positive & $1498(41.7)$ & $694(46.3)$ & $804(53.7)$ & \\
\hline
\end{tabular}

$1.56), 1.74(1.35-2.24)$, and $2.54(1.90-3.39)$, respectively. Similarly, $53.7 \%$ of the participants with insomnia experienced DS, which was a significantly higher proportion than that of participants without insomnia. Logistic regression showed that OR for DS among those with insomnia was 2.36 (2.04-2.74) after adjusting for general characteristics (Table 2). To test whether there is an interaction effect of WT and insomnia on DS, we further introduced an interaction value of WT $\times$ insomnia into the regression. The interaction coefficient was found to be 1.35 (1.15-1.59) with statistical significance (Table 2).

The interaction effect was then illustrated in two manners from different perspectives by showing the exact moderating effects of WT or insomnia on each other. 
Table 2 Analyses among work time, insomnia, and depression

\begin{tabular}{lllll}
\hline & Values to be analyzed & \multicolumn{3}{c}{ Depressive symptom } \\
\cline { 3 - 5 } & & ORa & $\mathbf{9 5 \% C l}$ & $\boldsymbol{p}$-value \\
\hline Model 1 & WT & & & \\
& $\leq 40 \mathrm{~h} /$ week & - & - & - \\
& $41-50 \mathrm{~h} /$ week & 1.32 & $1.11-1.56$ & $<0.001$ \\
& $51-60 \mathrm{~h} /$ week & 1.74 & $1.35-2.24$ & $<0.001$ \\
& $>60 \mathrm{~h} /$ week & 2.54 & $1.90-3.39$ & $<0.001$ \\
& Insomnia & & & \\
& Negative & - & - & \\
& Positive & 2.36 & $2.04-2.74$ & $<0.001$ \\
Model 2 & WT $\times$ Insomnia & 1.35 & $1.15-1.59$ & $<0.001$ \\
& Nagelkerke R2 & 0.171 & & \\
\hline
\end{tabular}

Note: Model 1: work time and insomnia were simultaneously introduced into the regression adjusted by sex, age, education level, marital status, income, exercise frequency, dietary habits, and smoking status. Model 2 further introduced an interaction value of WT $\times$ insomnia based on Model 1; only the interaction coefficient is shown in Table 2 . WT of interaction value in model 2 was introduced as a continuous variable. WT work time; a: $p<0.05$; $C l$ confident interval; ORa odds ratio adjusted by general characteristics such as sex, age, education level, marital status, income, exercise frequency, dietary habits, and smoking status

We first tested the association of insomnia with DS within each category of WT through a stratified regression analysis, as shown in Table 3 . The results show that the association of insomnia with DS relies on the number of hours for which employees work. Insomnia showed increasing ORs for DS as WT increased. The ORs for DS related to insomnia are similar [1.91 (1.46$2.50)$ and $2.00(1.61-2.50)$, respectively] in the participants who worked for $<50 \mathrm{~h} /$ week. However, among the participants working for $51-60$ or $>60 \mathrm{~h} /$ week, the adjusted ORs substantially increased to $4.62(2.90-7.37)$ and 5.60 (3.36-9.33), respectively (Table 3 ).

For assessing the association between WT and DS moderated by insomnia, another stratified regression analysis was conducted. The results indicated that for participants without insomnia, working overtime but for $<60 \mathrm{~h} /$ week showed a relatively weak association with DS [adjusted ORs: 1.30 (1.03-1.65) and 1.30 (0.91-1.86) for 41-50 and 51-60 h/week, respectively]. However, participants working for $>60 \mathrm{~h} /$ week showed a significant OR of $1.82(1.23-2.69)$ compared with those working for $\leq 40 \mathrm{~h} /$ week (reference group). Conversely, among participants with insomnia, working overtime showed a greater influence on DS. The adjusted ORs for 41-50, 51-60, and $>60 \mathrm{~h} /$ week were 1.35 (1.06-1.73), 2.48 (1.70-3.62), and 4.16 (2.62$6.60)$, respectively, compared with the reference group of $\leq 40 \mathrm{~h} /$ week (Table 4 ).

\section{Discussion}

The present study assessed the relationship among long working hours, insomnia, and DS. The results confirmed our hypotheses that long working hours and insomnia are both independent factors associated with the prevalence of DS among internet company employees. In addition, there exists an interaction effect of long working hours and insomnia on DS. Particularly, among those with insomnia, a dose-response relationship was observed between working hours and DS; the ORs for DS were more than double for those working for 51-60 $\mathrm{h} /$ week and more than four-fold for those working for $>$ $60 \mathrm{~h} /$ week compared with those working for $<40 \mathrm{~h} /$ week. Among those without insomnia, the association between working hours and DS was more modest, with elevated odds of DS seen primarily among those working for $>60 \mathrm{~h} /$ week.

In the present study, working overtime was one of the predictors of DS. This finding was consistent with the systematic reviews and/or meta-analyses, which have reported a positive association between long working hours and depression [4, 34, 35]. Owing to working overtime, less time is available for social activities, leading to damage to interpersonal relationships, social exchange, and social support, which are suggested as beneficial factors for personal mental health [36]. As indicated by Kleppa, working overtime is essentially a job stressor having a clear association with adverse mental health [37]. The physiological recovery theory states that recovery activities, such as sleeping, exercising, or eating, are greatly nullified by working overtime, resulting in less time to relax or efficiently recover [38, 39]. Insufficient recovery can disturb physiological processes (blood pressure, hormone excretion, and sympathetic nervous

Table 3 Effects of insomnia on depression moderated by work time

\begin{tabular}{|c|c|c|c|c|}
\hline \multirow[t]{3}{*}{ Insomnia } & \multicolumn{4}{|c|}{ Depressive symptom } \\
\hline & WT: $\leq 40 \mathrm{~h}$ & WT: $41-50 \mathrm{~h}$ & WT: $51-60 \mathrm{~h}$ & WT: $>60 \mathrm{~h}$ \\
\hline & ORa $(95 \% \mathrm{Cl})$ & ORa $(95 \% C l)$ & ORa $(95 \% C l)$ & ORa $(95 \% C l)$ \\
\hline Negative & - & - & - & - \\
\hline Positive & $1.91(1.46-2.50)$ & $2.00(1.61-2.50)$ & $4.62(2.90-7.37)$ & $5.60(3.36-9.33)$ \\
\hline Nagelkerke R2 & 0.143 & 0.191 & 0.313 & 0.284 \\
\hline
\end{tabular}

Note: $W T$ work time; ORa odds ratio adjusted by sex, age, education level, marital status, income, exercise frequency, dietary habits, and smoking status. Cl confidence interval 
Table 4 Effects of work time on depression moderated by insomnia

\begin{tabular}{lll}
\hline Work time & \multicolumn{2}{l}{ Depressive symptom } \\
\cline { 2 - 3 } & $\begin{array}{l}\text { Insomnia negative } \\
\text { ORa }(\mathbf{9 5 \%} \mathrm{Cl})\end{array}$ & $\begin{array}{l}\text { Insomnia positive } \\
\text { ORa }(\mathbf{9 5 \%} \% \mathbf{C l}\end{array}$ \\
\hline $\mathbf{4 0 0} \mathbf{h} /$ week & - & - \\
$\mathbf{4 1 - 5 0} \mathbf{h} /$ week & $1.30(1.03-1.65)$ & $1.35(1.06-1.73)$ \\
$\mathbf{5 1 - 6 0} \mathbf{h} /$ week & $1.30(0.91-1.86)$ & $2.48(1.70-3.62)$ \\
$\mathbf{5} \mathbf{6 0}$ h/week & $1.82(1.23-2.69)$ & $4.16(2.62-6.60)$ \\
Nagelkerke R2 & 0.133 & 0.104 \\
\hline
\end{tabular}

Note: WT work time; ORa odds ratio adjusted by general characteristics as sex, age, education level, marital status, income, exercise frequency, dietary habits, and smoking status; $\mathrm{Cl}$ confidence interval

system activity), eventually leading to psychological and physical health issues [40].

The results of our study are consistent with those of previous studies and theoretical inferences. Kleppa reported that overtime workers of both sexes have significantly higher levels of anxiety and depression and a higher prevalence of anxiety and depressive disorders than those working for normal hours [37]. In a cross-sectional study, Nishikitani found that working overtime was associated with increased Hamilton Depression Scale scores using univariate analysis [41], and Proctor determined that extended hours were associated with higher levels of depression [42]. Tyssen focused on suicidal tendencies, which can be considered as a severe depression-related outcome, and reported that longer working hours were associated with suicidal tendencies [43].

Insomnia has conventionally been conceptualized as a symptom of psychopathology, particularly depression [44]. More recently, insomnia has been considered a primary disorder if it is present without other clinically relevant psychiatric or medical diseases; otherwise, it was considered a secondary disorder [23]. Nevertheless, with respect to the association with depression, chronic insomnia can exist for years before the first onset of a depressive episode.

Our results suggested that insomnia is independently associated with DS among internet company employees. As proposed by Vandekerckhove, adequate sleep restores vitality for each working day, whereas employees with insufficient sleep were more sensitive to negative emotions and stressful events at work [45]. Moreover, daytime sleepiness resulting from insomnia can undermine attention, reactivity, and efficiency at work. Sleep dysfunction is reportedly associated with depersonalization toward learning among medical students, indicating that sleep disturbances reduce personal motivation at work. This reduced motivation ultimately promotes diffidence to academic learning and interferes with cognitive functions and self-assessment, resulting in mood dysfunction, such as depression [46]. In our study population, insomnia may lessen the ability of internet employees to tolerate the stressful work environment by interfering with sleep quality and quantity. Therefore, the results of the present study suggest that insomnia risks the mental health of those working in stressful environments such as internet companies.

Furthermore, a significant interaction effect of long working hours and insomnia on DS has been detected. Our results showed that the impact of working hours on DS varies between participants with or without insomnia and suggest that compared with the employees getting good sleep, those who experience insomnia and with long working hours have little chance to recover at night. Additional attention should be paid to employees with poor sleep quality when WT gets extended. On the other hand, working overtime shows more impact on the rate of DS in participants with insomnia than in those without insomnia. Further, a dose-response relationship appeared to exist between working hours and DS insomnia condition, considering the potential that along with the extension of working hours, employees with insomnia experience prolonged fatigue and frustration, thereby increasing the morbidity of DS.

This is the first study to investigate the independent and interaction effect of long working hours and insomnia on DS among internet company employees in China. The working hours followed in China are among the longest in the world; however, correlational research on long working hours remains limited.

There are some study limitations. First, the restricted type of occupation limited the extrapolation of conclusions to other professions. Moreover, the cross-sectional design cannot lead to any causal conclusion, which should be clarified in future prospective studies. Second, information was collected using self-administered questionnaires, which may lead to an increased risk of data unreliability. Furthermore, WT and insomnia were evaluated using a retrospective questionnaire, and recall bias could have influenced the interpretation of our exploratory findings.

\section{Conclusion}

In this exploratory study with 3589 full-time employees from 35 internet companies, long working hours and insomnia are independent risk factors associated with DS. Moreover, interaction effects between WT and insomnia on DS were detected. The results suggest that to relieve 
DS, reducing insomnia is important, particularly among employees working for excessive hours at internet companies. Nevertheless, public policies promoting the reduction of working hours are warranted. Sometimes, long working hours may be inevitable; workers and enterprises should be informed of the potential risk and interventions that might mitigate the risk.

\section{Abbreviations}

DS: Depressive symptoms; PHQ-9: The patient health questionnaire; ORs: Odds ratios; DIS: Difficulty initiating sleep; DMS: Difficulty maintaining sleep; EMA: Early morning awakening; WT: Work time; Cl: Confidence interval

\section{Supplementary Information}

The online version contains supplementary material available at https://doi. org/10.1186/s12889-021-11454-9.

Additional file 1: Supplementary file 1. The Sleep Questionnaire (睡 眠问卷)

\section{Acknowledgments}

The authors would like to express their sincere gratitude to all field workers and participants of this study.

\section{Authors' contributions}

$\mathrm{XL}$ designed and wrote the manuscript. CW analyzed and interpreted the findings, co-authored the manuscript. JW and YJ collected data and revised the paper. LS designed, reviewed, and revised the manuscript and approved the final manuscript as submitted. All authors read and approved the final manuscript.

\section{Funding}

This study was supported by the Central Financial Project of Occupational Health Institute, Chinese Center for Disease Control and Prevention (grant number 131031109000160008).

\section{Availability of data and materials}

Original data are available on reasonable request. These were stored on password-protected computers at the National Institute of Occupational Health and Poison Control, Chinese Center for Disease Control and Prevention, Beijing, China. Readers who wish to gain access to the data can write to the corresponding author.

\section{Declarations}

\section{Ethics approval and consent to participate}

The study protocol was approved by the Medical Ethics Committee of the National Institute of Occupational Health and Poison Control (Code No. 201502). All participants gave written informed consent before recruited into the study.

\section{Consent for publication}

Not applicable.

\section{Competing interests}

The authors declare that they have no competing interests.

\section{Author details}

${ }^{1}$ National Institute of Occupational Health and Poison Control, Chinese Center for Disease Control and Prevention, 29 Nanwei Road, Xicheng District, Beijing, P.R. China 100050. ${ }^{2}$ Department of Laboratory Science and Technology \& Vaccine Research Center, School of Public Health, Peking University, No.38 Xueyuan Road, Haidian District, Beijing, P.R. China 100191.
Received: 15 September 2020 Accepted: 6 July 2021

Published online: 16 July 2021

\section{References}

1. Ye J. The impact of China's "996" debate on foreign IT companies. 2019. https://hrmasia.com/the-impact-of-chinas-996-debate-on-foreign-it-compa nies/. Accessed 18 Aug 2020.

2. Chen C.bye 996. The Internet Economy. 2019;(5):68-73. https://doi.org/10.3 969/j.issn.2095-8560.2019.05.011.

3. Kivimaki M, Jokela M, Nyberg ST, Singh-Manoux A,Fransson El, Alfredsson L, et al. Long working hours and risk of coronary heart disease and stroke: a systematic review and meta-analysis of published and unpublished data for 603,838 individuals. Lancet.2015;386(10005):1739-1746. https://doi.org/ https://doi.org/10.1016/S0140-6736(15)60295-1.

4. Rivera AS, Akanbi M, O'Dwyer LC, McHugh M. Shift work and long work hours and their association with chronic health conditions: a systematic review of systematic reviews with meta-analyses. PLoS One 2020;15(4):1-19. http://doi.org/https://doi.org/10.1371/journal.pone.0231037.

5. Li Z, Dai J, Wu N, Jia YN, Gao JL, Fu H. Effect of long working hours on depression and mental well-being among employees in Shanghai: the role of having leisure hobbies. Int J Environ Res Public Health. 2019;16(24):4980. https://doi.org/10.3390/ijerph16244980.

6. Li KY, Zhao QK, Huang HT, Zhang XT, Liu WZ, Wang ZB. An overview of recognition criteria of Karoshi in China, Japan and Korea. Occupational Health and Emergency Rescue. 2019;37(5):500-6. https://doi.org/10.16369/j. oher.issn.1007-1326.2019.05.028.

7. James SL, Abate D, Abate KH, Abay SM, Abbafati C, Abbasi N, Abbastabar H, Abd-Allah F, Abdela J, Abdelalim A, Abdollahpour I, Abdulkader RS, Abebe Z, Abera SF, Abil OZ, Abraha HN, Abu-Raddad LJ, Abu-Rmeileh NME, Accrombessi MMK, Acharya D, Acharya P, Ackerman IN, Adamu AA, Adebayo OM, Adekanmbi V, Adetokunboh OO, Adib MG, Adsuar JC, Afanvi KA, Afarideh M, Afshin A, Agarwal G, Agesa KM, Aggarwal R, Aghayan SA, Agrawal S, Ahmadi A, Ahmadi M, Ahmadieh H, Ahmed MB, Aichour AN, Aichour I, Aichour MTE, Akinyemiju T, Akseer N, al-Aly Z, al-Eyadhy A, alMekhlafi HM, al-Raddadi RM, Alahdab F, Alam K, Alam T, Alashi A, Alavian SM, Alene KA, Alijanzadeh M, Alizadeh-Navaei R, Aljunid SM, Alkerwi A', Alla F, Allebeck P, Alouani MML, Altirkawi K, Alvis-Guzman N, Amare AT, Aminde LN, Ammar W, Amoako YA, Anber NH, Andrei CL, Androudi S, Animut MD, Anjomshoa M, Ansha MG, Antonio CAT, Anwari P, Arabloo J, Arauz A, Aremu O, Ariani F, Armoon B, Ärnlöv J, Arora A, Artaman A, Aryal KK, Asayesh H, Asghar RJ, Ataro Z, Atre SR, Ausloos M, Avila-Burgos L, Avokpaho EFGA, Awasthi A, Ayala Quintanilla BP, Ayer R, Azzopardi PS, Babazadeh A, Badali H, Badawi A, Bali AG, Ballesteros KE, Ballew SH, Banach M, Banoub JAM, Banstola A, Barac A, Barboza MA, Barker-Collo SL, Bärnighausen TW, Barrero LH, Baune BT, Bazargan-Hejazi S, Bedi N, Beghi E, Behzadifar M, Behzadifar M, Béjot Y, Belachew AB, Belay YA, Bell ML, Bello AK, Bensenor IM, Bernabe E, Bernstein RS, Beuran M, Beyranvand T, Bhala N, Bhattarai $S$, Bhaumik S, Bhutta ZA, Biadgo B, Bijani A, Bikbov B, Bilano V, Bililign N, Bin Sayeed MS, Bisanzio D, Blacker BF, Blyth FM, Bou-Orm IR, Boufous S, Bourne R, Brady OJ, Brainin M, Brant LC, Brazinova A, Breitborde NJK, Brenner $H$, Briant PS, Briggs AM, Briko AN, Britton G, Brugha T, Buchbinder R, Busse R, Butt ZA, Cahuana-Hurtado L, Cano J, Cárdenas R, Carrero JJ, Carter A, Carvalho F, Castañeda-Orjuela CA, Castillo Rivas J, Castro F, Catalá-López F, Cercy KM, Cerin E, Chaiah Y, Chang AR, Chang HY, Chang JC, Charlson FJ, Chattopadhyay A, Chattu VK, Chaturvedi P, Chiang PPC, Chin KL, Chitheer A, Choi JYJ, Chowdhury R, Christensen H, Christopher DJ, Cicuttini FM, Ciobanu LG, Cirillo M, Claro RM, Collado-Mateo D, Cooper C, Coresh J, Cortesi PA, Cortinovis M, Costa M, Cousin E, Criqui MH, Cromwell EA, Cross M, Crump JA, Dadi AF, Dandona L, Dandona R, Dargan PI, Daryani A, Das Gupta R, Das Neves J, Dasa TT, Davey G, Davis AC, Davitoiu DV, de Courten $B$, de la Hoz FP, de Leo D, de Neve JW, Degefa MG, Degenhardt $L$, Deiparine S, Dellavalle RP, Demoz GT, Deribe K, Dervenis N, Des Jarlais DC, Dessie GA, Dey S, Dharmaratne SD, Dinberu MT, Dirac MA, Djalalinia S, Doan L, Dokova K, Doku DT, Dorsey ER, Doyle KE, Driscoll TR, Dubey M, Dubljanin E, Duken EE, Duncan BB, Duraes AR, Ebrahimi H, Ebrahimpour S, Echko MM, Edvardsson D, Effiong A, Ehrlich JR, el Bcheraoui C, el Sayed Zaki M, elKhatib Z, Elkout H, Elyazar IRF, Enayati A, Endries AY, Er B, Erskine HE, Eshrati B, Eskandarieh S, Esteghamati A, Esteghamati S, Fakhim H, Fallah Omrani V, Faramarzi M, Fareed M, Farhadi F, Farid TA, Farinha CSE, Farioli A, Faro A, Farvid MS, Farzadfar F, Feigin VL, Fentahun N, Fereshtehnejad SM, Fernandes E, Fernandes JC, Ferrari AJ, Feyissa GT, Filip I, Fischer F, 
Fitzmaurice C, Foigt NA, Foreman KJ, Fox J, Frank TD, Fukumoto T, Fullman N, Fürst T, Furtado JM, Futran ND, Gall S, Ganji M, Gankpe FG, GarciaBasteiro AL, Gardner WM, Gebre AK, Gebremedhin AT, Gebremichael TG, Gelano TF, Geleijnse JM, Genova-Maleras R, Geramo YCD, Gething PW, Gezae KE, Ghadiri K, Ghasemi Falavarjani K, Ghasemi-Kasman M, Ghimire M, Ghosh R, Ghoshal AG, Giampaoli S, Gill PS, Gill TK, Ginawi IA, Giussani G, Gnedovskaya EV, Goldberg EM, Goli S, Gómez-Dantés H, Gona PN, Gopalani SV, Gorman TM, Goulart AC, Goulart BNG, Grada A, Grams ME, Grosso G, Gugnani HC, Guo Y, Gupta PC, Gupta R, Gupta R, Gupta T, Gyawali B, Haagsma JA, Hachinski V, Hafezi-Nejad N, Haghparast Bidgoli H, Hagos TB, Hailu GB, Haj-Mirzaian A, Haj-Mirzaian A, Hamadeh RR, Hamidi S, Handal AJ, Hankey GJ, Hao Y, Harb HL, Harikrishnan S, Haro JM, Hasan M, Hassankhani H, Hassen HY, Havmoeller R, Hawley CN, Hay RJ, Hay Sl, HedayatizadehOmran A, Heibati B, Hendrie D, Henok A, Herteliu C, Heydarpour S, Hibstu DT, Hoang HT, Hoek HW, Hoffman HJ, Hole MK, Homaie Rad E, Hoogar P, Hosgood HD, Hosseini SM, Hosseinzadeh M, Hostiuc M, Hostiuc S, Hotez PJ, Hoy DG, Hsairi M, Htet AS, Hu G, Huang JJ, Huynh CK, Iburg KM, Ikeda CT, Ileanu B, llesanmi OS, Iqbal U, Irvani SSN, Irvine CMS, Islam SMS, Islami F, Jacobsen KH, Jahangiry L, Jahanmehr N, Jain SK, Jakovljevic M, Javanbakht M, Jayatilleke AU, Jeemon $P$, Jha RP, Jha V, Ji JS, Johnson CO, Jonas JB, Jozwiak JJ, Jungari SB, Jürisson M, Kabir Z, Kadel R, Kahsay A, Kalani R, Kanchan T, Karami M, Karami Matin B, Karch A, Karema C, Karimi N, Karimi SM, Kasaeian A, Kassa DH, Kassa GM, Kassa TD, Kassebaum NJ, Katikireddi SV, Kawakami N, Karyani AK, Keighobadi MM, Keiyoro PN, Kemmer L, Kemp GR, Kengne AP, Keren A, Khader YS, Khafaei B, Khafaie MA, Khajavi A, Khalil IA, Khan EA, Khan MS, Khan MA, Khang YH, Khazaei M, Khoja AT, Khosravi A, Khosravi MH, Kiadaliri AA, Kirithio DN, Kim Cl, Kim D, Kim P, Kim YE, Kim YJ, Kimokoti RW, Kinfu Y, Kisa A, Kissimova-Skarbek K, Kivimäki M, Knudsen AKS, Kocarnik JM, Kochhar S, Kokubo Y, Kolola T, Kopec JA, Kosen S, Kotsakis GA, Koul PA, Koyanagi A, Kravchenko MA, Krishan K, Krohn KJ, Kuate Defo B, Kucuk Bicer B, Kumar GA, Kumar M, Kyu HH, Lad DP, Lad SD, Lafranconi A, Lalloo R, Lallukka T, Lami FH, Lansingh VC, Latifi A, Lau KMM, Lazarus JV, Leasher JL, Ledesma JR, Lee PH, Leigh J, Leung J, Levi M, Lewycka S, Li S, Li Y, Liao Y, Liben ML, Lim LL, Lim SS, Liu S, Lodha R, Looker KJ, Lopez AD, Lorkowski S, Lotufo PA, Low N, Lozano R, Lucas TCD, Lucchesi LR, Lunevicius R, Lyons RA, Ma S, Macarayan ERK, Mackay MT, Madotto F, Magdy Abd el Razek H, Magdy Abd el Razek M, Maghavani DP, Mahotra NB, Mai HT, Majdan M, Majdzadeh R, Majeed A, Malekzadeh R, Malta DC, Mamun AA, Manda AL, Manguerra H, Manhertz T, Mansournia MA, Mantovani LG, Mapoma CC, Maravilla JC, Marcenes W, Marks A, MartinsMelo FR, Martopullo I, März W, Marzan MB, Mashamba-Thompson TP, Massenburg BB, Mathur MR, Matsushita K, Maulik PK, Mazidi M, McAlinden C, McGrath JJ, McKee M, Mehndiratta MM, Mehrotra R, Mehta KM, Mehta V, Mejia-Rodriguez F, Mekonen T, Melese A, Melku M, Meltzer M, Memiah PTN, Memish ZA, Mendoza W, Mengistu DT, Mengistu G, Mensah GA, Mereta ST, Meretoja A, Meretoja TJ, Mestrovic T, Mezerji NMG, Miazgowski B, Miazgowski T, Millear Al, Miller TR, Miltz B, Mini GK, Mirarefin M, Mirrakhimov EM, Misganaw AT, Mitchell PB, Mitiku H, Moazen B, Mohajer B, Mohammad KA, Mohammadifard N, Mohammadnia-Afrouzi M, Mohammed MA, Mohammed S, Mohebi F, Moitra M, Mokdad AH, Molokhia M, Monasta L, Moodley Y, Moosazadeh M, Moradi G, Moradi-Lakeh M, Moradinazar M, Moraga P, Morawska L, Moreno Velásquez I, Morgado-da-Costa J, Morrison SD, Moschos MM, Mountjoy-Venning WC, Mousavi SM, Mruts KB, Muche AA, Muchie KF, Mueller UO, Muhammed OS, Mukhopadhyay S, Muller K, Mumford JE, Murhekar M, Musa J, Musa KI, Mustafa G, Nabhan AF, Nagata C, Naghavi M, Naheed A, Nahvijou A, Naik G, Naik N, Najafi F, Naldi L, Nam HS, Nangia V, Nansseu JR, Nascimento BR, Natarajan G, Neamati N, Negoi I, Negoi RI, Neupane S, Newton CRJ, Ngunjiri JW, Nguyen AQ, Nguyen HT, Nguyen HLT, Nguyen HT, Nguyen LH, Nguyen M, Nguyen NB, Nguyen SH, Nichols E, Ningrum DNA, Nixon MR, Nolutshungu N, Nomura S, Norheim OF, Noroozi M, Norrving B, Noubiap JJ, Nouri HR, Nourollahpour Shiadeh M, Nowroozi MR, Nsoesie EO, Nyasulu PS, Odell CM, Ofori-Asenso R, Ogbo FA, Oh $\mathrm{IH}$, Oladimeji O, Olagunju AT, Olagunju TO, Olivares PR, Olsen HE, Olusanya BO, Ong KL, Ong SK, Oren E, Ortiz A, Ota E, Otstavnov SS, Øverland S, Owolabi MO, P A M, Pacella R, Pakpour AH, Pana A, PandaJonas S, Parisi A, Park EK, Parry CDH, Patel S, Pati S, Patil ST, Patle A, Patton GC, Paturi VR, Paulson KR, Pearce N, Pereira DM, Perico N, Pesudovs K, Pham HQ, Phillips MR, Pigott DM, Pillay JD, Piradov MA, Pirsaheb M, Pishgar F, Plana-Ripoll O, Plass D, Polinder S, Popova S, Postma MJ, Pourshams A, Poustchi H, Prabhakaran D, Prakash S, Prakash V, Purcell CA, Purwar MB, Qorbani M, Quistberg DA, Radfar A, Rafay A, Rafiei A, Rahim F, Rahimi K,
Rahimi-Movaghar A, Rahimi-Movaghar V, Rahman M, Rahman MH, Rahman MA, Rahman SU, Rai RK, Rajati F, Ram U, Ranjan P, Ranta A, Rao PC, Rawaf DL, Rawaf S, Reddy KS, Reiner RC, Reinig N, Reitsma MB, Remuzzi G, Renzaho AMN, Resnikoff S, Rezaei S, Rezai MS, Ribeiro ALP, Roberts NLS, Robinson SR, Roever L, Ronfani L, Roshandel G, Rostami A, Roth GA, Roy A, Rubagotti E, Sachdev PS, Sadat N, Saddik B, Sadeghi E, Saeedi Moghaddam S, Safari H, Safari Y, Safari-Faramani R, Safdarian M, Safi S, Safiri S, Sagar R, Sahebkar A, Sahraian MA, Sajadi HS, Salam N, Salama JS, Salamati P, Saleem K, Saleem Z, Salimi Y, Salomon JA, Salvi SS, Salz I, Samy AM, Sanabria J, Sang Y, Santomauro DF, Santos IS, Santos JV, Santric Milicevic MM, Sao Jose BP, Sardana M, Sarker AR, Sarrafzadegan N, Sartorius B, Sarvi S, Sathian B, Satpathy M, Sawant AR, Sawhney M, Saxena S, Saylan M, Schaeffner E, Schmidt MI, Schneider IJC, Schöttker B, Schwebel DC, Schwendicke F, Scott JG, Sekerija M, Sepanlou SG, Serván-Mori E, Seyedmousavi S, Shabaninejad H, Shafieesabet A, Shahbazi M, Shaheen AA, Shaikh MA, Shams-Beyranvand M, Shamsi M, Shamsizadeh M, Sharafi H, Sharafi K, Sharif M, Sharif-Alhoseini M, Sharma M, Sharma R, She J, Sheikh A, Shi P, Shibuya K, Shigematsu M, Shiri R, Shirkoohi R, Shishani K, Shiue I, Shokraneh F, Shoman H, Shrime MG, Si S, Siabani S, Siddiqi TJ, Sigfusdottir ID, Sigurvinsdottir R, Silva JP, Silveira DGA, Singam NSV, Singh JA, Singh NP, Singh V, Sinha DN, Skiadaresi E, Slepak ELN, Sliwa K, Smith DL, Smith M, Soares Filho AM, Sobaih BH, Sobhani S, Sobngwi E, Soneji SS, Soofi M, Soosaraei M, Sorensen RJD, Soriano JB, Soyiri IN, Sposato LA, Sreeramareddy CT, Srinivasan V, Stanaway JD, Stein DJ, Steiner C, Steiner TJ, Stokes MA, Stovner LJ, Subart ML, Sudaryanto A, Sufiyan M'B, Sunguya BF, Sur PJ, Sutradhar I, Sykes BL, Sylte DO, Tabarés-Seisdedos R, Tadakamadla SK, Tadesse BT, Tandon N, Tassew SG, Tavakkoli M, Taveira N, Taylor HR, Tehrani-Banihashemi A, Tekalign TG, Tekelemedhin SW, Tekle MG, Temesgen H, Temsah MH, Temsah O, Terkawi AS, Teweldemedhin M, Thankappan KR, Thomas N, Tilahun B, To QG, Tonelli M, Topor-Madry R, Topouzis F, Torre AE, Tortajada-Girbés M, Touvier M, Tovani-Palone MR, Towbin JA, Tran BX, Tran KB, Troeger CE, Truelsen TC, Tsilimbaris MK, Tsoi D, Tudor Car L, Tuzcu EM, Ukwaja KN, Ullah I, Undurraga EA, Unutzer J, Updike RL, Usman MS, Uthman OA, Vaduganathan M, Vaezi A, Valdez PR, Varughese S, Vasankari TJ, Venketasubramanian N, Villafaina S, Violante FS, Vladimirov SK, Vlassov V, Vollset SE, Vosoughi K, Vujcic IS, Wagnew FS, Waheed Y, Waller SG, Wang Y, Wang YP, Weiderpass E, Weintraub RG, Weiss DJ, Weldegebreal F, Weldegwergs KG, Werdecker A, West TE, Whiteford HA, Widecka J, Wijeratne T, Wilner LB, Wilson S, Winkler $A S$, Wiyeh AB, Wiysonge CS, Wolfe CDA, Woolf AD, Wu S, Wu YC, Wyper GMA, Xavier D, Xu G, Yadgir S, Yadollahpour A, Yahyazadeh Jabbari SH, Yamada T, Yan LL, Yano Y, Yaseri M, Yasin YJ, Yeshaneh A, Yimer EM, Yip P, Yisma E, Yonemoto N, Yoon SJ, Yotebieng M, Younis MZ, Yousefifard M, Yu C, Zadnik V, Zaidi Z, Zaman SB, Zamani M, Zare Z, Zeleke AJ, Zenebe ZM, Zhang K, Zhao Z, Zhou M, Zodpey S, Zucker I, Vos T, Murray CJL Global, regional, and national incidence, prevalence, and years lived with disability for 354 diseases and injuries for 195 countries and territories, 1990-2017: a systematic analysis for the global burden of disease study 2017. Lancet. 2018;392(10159):1789-1858. https://doi.org/10.1016/S0140-6736(18)32279-7.

8. Ma X, Xiang YT, Cai ZJ, Li SR, Xiang YQ, Guo HL, Hou YZ, Li ZB, Li ZJ, Tao YF, Dang WM, Wu XM, Deng J, Wang CY, Lai KYC, Ungvari GS Prevalence and socio-demographic correlates of major depressive episode in rural and urban areas of Beijing, China. J Affect Disord2009;1 15(3):323-330. https://doi. org/https://doi.org/10.1016/j.jad.2008.09.010.

9. Phillips MR, Zhang J, Shi Q, Song ZQ, Ding ZJ, Pang ST, Li X, Zhang Y, Wang $Z$ Prevalence, treatment, and associated disability of mental disorders in four provinces in China during 2001-05: an epidemiological survey. Lancet2009;373(9680):2041-2053. https://doi.org/https://doi.org/10.1016/ S0140-6736(09)60660-7.

10. Vos T, Allen C, Arora M, Barber RM, Bhutta ZA, Brown A, Carter A, Casey DC, Charlson FJ, Chen AZ, Coggeshall M, Cornaby L, Dandona L, Dicker DJ, Dilegge T, Erskine HE, Ferrari AJ, Fitzmaurice C, Fleming T, Forouzanfar MH, Fullman N, Gething PW, Goldberg EM, Graetz N, Haagsma JA, Hay SI, Johnson CO, Kassebaum NJ, Kawashima T, Kemmer L, Khalil IA, Kinfu Y, Kyu HH, Leung J, Liang X, Lim SS, Lopez AD, Lozano R, Marczak L, Mensah GA, Mokdad AH, Naghavi M, Nguyen G, Nsoesie E, Olsen H, Pigott DM, Pinho C, Rankin Z, Reinig N, Salomon JA, Sandar L, Smith A, Stanaway J, Steiner C, Teeple S, Thomas BA, Troeger C, Wagner JA, Wang H, Wanga V, Whiteford HA, Zoeckler L, Abajobir AA, Abate KH, Abbafati C, Abbas KM, Abd-Allah F, Abraham B, Abubakar I, Abu-Raddad LJ, Abu-Rmeileh NME, Ackerman IN, Adebiyi AO, Ademi Z, Adou AK, Afanvi KA, Agardh EE, Agarwal A, Kiadaliri AA, Ahmadieh H, Ajala ON, Akinyemi RO, Akseer N, al-Aly Z, Alam K, Alam 
NKM, Aldhahri SF, Alegretti MA, Alemu ZA, Alexander LT, Alhabib S, Ali R, Alkerwi A', Alla F, Allebeck $P$, al-Raddadi R, Alsharif U, Altirkawi KA, AlvisGuzman N, Amare AT, Amberbir A, Amini H, Ammar W, Amrock SM, Andersen $\mathrm{HH}$, Anderson GM, Anderson BO, Antonio CAT, Aregay AF, Ärnlöv J, Artaman A, Asayesh H, Assadi R, Atique S, Avokpaho EFGA, Awasthi A, Quintanilla BPA, Azzopardi P, Bacha U, Badawi A, Balakrishnan K, Banerjee A, Barac A, Barker-Collo SL, Bärnighausen T, Barregard L, Barrero LH, Basu A, Bazargan-Hejazi S, Beghi E, Bell B, Bell ML, Bennett DA, Bensenor IM, Benzian H, Berhane A, Bernabé E, Betsu BD, Beyene AS, Bhala N, Bhatt S, Biadgilign S, Bienhoff K, Bikbov B, Biryukov S, Bisanzio D, Bjertness E, Blore J, Borschmann R, Boufous S, Brainin M, Brazinova A, Breitborde NJK, Brown J, Buchbinder R, Buckle GC, Butt ZA, Calabria B, Campos-Nonato IR, Campuzano JC, Carabin H, Cárdenas R, Carpenter DO, Carrero JJ, Castañeda-Orjuela CA, Rivas JC, Catalá-López F, Chang JC, Chiang PPC, Chibueze CE, Chisumpa VH, Choi JYJ, Chowdhury R, Christensen H, Christopher DJ, Ciobanu LG, Cirillo M, Coates MM, Colquhoun SM, Cooper C, Cortinovis M, Crump JA, Damtew SA, Dandona R, Daoud F, Dargan PI, das Neves J, Davey G, Davis AC, Leo DD, Degenhardt L, Gobbo LCD, Dellavalle RP, Deribe K, Deribew A, Derrett S, Jarlais DCD, Dharmaratne SD, Dhillon PK, Diaz-Torné C, Ding EL, Driscoll TR, Duan L, Dubey M, Duncan BB, Ebrahimi H, Ellenbogen RG, Elyazar I, Endres M, Endries AY, Ermakov SP, Eshrati B, Estep K, Farid TA, Farinha CS S, Faro A, Farvid MS, Farzadfar F, Feigin VL, Felson DT, Fereshtehnejad SM, Fernandes $J G$, Fernandes JC, Fischer F, Fitchett JRA, Foreman K, Fowkes FGR, Fox J, Franklin RC, Friedman J, Frostad J, Fürst T, Futran ND, Gabbe B, Ganguly P, Gankpé FG, Gebre T, Gebrehiwot TT, Gebremedhin AT, Geleijnse JM, Gessner BD, Gibney KB, Ginawi IAM, Giref AZ, Giroud M, Gishu MD, Giussani G, Glaser E, Godwin WW, Gomez-Dantes H, Gona P, Goodridge A, Gopalani SV, Gotay CC, Goto A, Gouda HN, Grainger R, Greaves F, Guillemin F, Guo Y, Gupta R, Gupta R, Gupta V, Gutiérrez RA, Haile D, Hailu AD, Hailu GB, Halasa YA, Hamadeh RR, Hamidi S, Hammami M, Hancock J, Handal AJ, Hankey GJ, Hao Y, Harb HL, Harikrishnan S, Haro JM, Havmoeller R, Hay RJ, Heredia-Pi IB, Heydarpour P, Hoek HW, Horino M, Horita N, Hosgood HD, Hoy DG, Htet AS, Huang H, Huang JJ, Huynh C, lannarone M, Iburg KM, Innos K, Inoue M, lyer $\mathrm{VJ}$, Jacobsen $\mathrm{KH}$, Jahanmehr $\mathrm{N}$, Jakovljevic MB, Javanbakht $M$, Jayaraman $S P$, Jayatilleke $A U$, Jee $S H$, Jeemon $P$, Jensen $P N$, Jiang $Y$, Jibat $T$, Jimenez-Corona A, Jin Y, Jonas JB, Kabir Z, Kalkonde Y, Kamal R, Kan H, Karch A, Karema CK, Karimkhani C, Kasaeian A, Kaul A, Kawakami N, Keiyoro PN, Kemp AH, Keren A, Kesavachandran CN, Khader YS, Khan AR, Khan EA, Khang YH, Khera S, Khoja TAM, Khubchandani J, Kieling C, Kim P, Kim Cl, Kim D, Kim YJ, Kissoon N, Knibbs LD, Knudsen AK, Kokubo Y, Kolte D, Kopec JA, Kosen S, Kotsakis GA, Koul PA, Koyanagi A, Kravchenko M, Defo BK, Bicer BK, Kudom AA, Kuipers EJ, Kumar GA, Kutz M, Kwan GF, Lal A, Lalloo R, Lallukka T, Lam H, Lam JO, Langan SM, Larsson A, Lavados PM, Leasher JL, Leigh J, Leung R, Levi M, Li Y, Li Y, Liang J, Liu S, Liu Y, Lloyd BK, Lo WD, Logroscino G, Looker KJ, Lotufo PA, Lunevicius R, Lyons RA, Mackay MT, Magdy M, Razek AE, Mahdavi M, Majdan M, Majeed A, Malekzadeh R, Marcenes W, Margolis DJ, Martinez-Raga J, Masiye F, Massano J, McGarvey ST, McGrath JJ, McKee M, McMahon BJ, Meaney PA, Mehari A, MejiaRodriguez F, Mekonnen AB, Melaku YA, Memiah P, Memish ZA, Mendoza W, Meretoja A, Meretoja TJ, Mhimbira FA, Millear A, Miller TR, Mills EJ, Mirarefin M, Mitchell PB, Mock CN, Mohammadi A, Mohammed S, Monasta L, Hernandez JCM, Montico M, Mooney MD, Moradi-Lakeh M, Morawska L, Mueller UO, Mullany E, Mumford JE, Murdoch ME, Nachega JB, Nagel G, Naheed A, Naldi L, Nangia V, Newton JN, Ng M, Ngalesoni FN, Nguyen QL, Nisar MI, Pete PMN, Nolla JM, Norheim OF, Norman RE, Norrving B, Nunes BP, Ogbo FA, Oh IH, Ohkubo T, Olivares PR, Olusanya BO, Olusanya JO, Ortiz A, Osman M, Ota E, PA M, Park EK, Parsaeian M, de Azeredo Passos VM, Caicedo AJP, Patten SB, Patton GC, Pereira DM, Perez-Padilla R, Perico N, Pesudovs K, Petzold M, Phillips MR, Piel FB, Pillay JD, Pishgar F, Plass D, Platts-Mills JA, Polinder S, Pond CD, Popova S, Poulton RG, Pourmalek F, Prabhakaran D, Prasad NM, Qorbani M, Rabiee RHS, Radfar A, Rafay A, Rahimi K, Rahimi-Movaghar V, Rahman M, Rahman MHU, Rahman SU, Rai RK, Rajsic S, Ram U, Rao P, Refaat AH, Reitsma MB, Remuzzi G, Resnikoff S, Reynolds A, Ribeiro AL, Blancas MJR, Roba HS, Rojas-Rueda D, Ronfani L, Roshandel G, Roth GA, Rothenbacher D, Roy A, Sagar R, Sahathevan R, Sanabria JR, Sanchez-Niño MD, Santos IS, Santos JV, Sarmiento-Suarez R, Sartorius B, Satpathy M, Savic M, Sawhney M, Schaub MP, Schmidt MI, Schneider IJC, Schöttker B, Schwebel DC, Scott JG, Seedat S, Sepanlou SG, Servan-Mori EE, Shackelford KA, Shaheen A, Shaikh MA, Sharma R, Sharma U, Shen J, Shepard DS, Sheth KN, Shibuya K, Shin MJ, Shiri R, Shiue I, Shrime MG, Sigfusdottir ID, Silva DAS, Silveira DGA, singh A, singh JA, singh OP,
Singh PK, Sivonda A, Skirbekk V, Skogen JC, Sligar A, Sliwa K, Soljak M, Søreide K, Sorensen RJD, Soriano JB, Sposato LA, Sreeramareddy CT, Stathopoulou V, Steel N, Stein DJ, Steiner TJ, Steinke S, Stovner L, Stroumpoulis K, Sunguya BF, Sur P, Swaminathan S, Sykes BL, Szoeke CEl, Tabarés-Seisdedos R, Takala JS, Tandon N, Tanne D, Tavakkoli M, Taye B, Taylor HR, Ao BJT, Tedla BA, Terkawi AS, Thomson AJ, Thorne-Lyman AL, Thrift AG, Thurston GD, Tobe-Gai R, Tonelli M, Topor-Madry R, Topouzis F, Tran BX, Truelsen T, Dimbuene ZT, Tsilimbaris M, Tura AK, Tuzcu EM, Tyrovolas S, Ukwaja KN, Undurraga EA, Uneke CJ, Uthman OA, van Gool CH, Varakin YY, Vasankari T, Venketasubramanian N, Verma RK, Violante FS, Vladimirov SK, Vlassov W, Vollset SE, Wagner GR, Waller SG, Wang L, Watkins DA, Weichenthal S, Weiderpass E, Weintraub RG, Werdecker A, Westerman R, White RA, Williams HC, Wiysonge CS, Wolfe CDA, Won S, Woodbrook R, Wubshet M, Xavier D, Xu G, Yadav AK, Yan LL, Yano Y, Yaseri M, Ye P, Yebyo HG, Yip P, Yonemoto N, Yoon SJ, Younis MZ, Yu C, Zaidi Z, Zaki MES, Zeeb H, Zhou M, Zodpey S, Zuhlke LJ, Murray CJL Global, regional, and national incidence, prevalence, and years lived with disability for 310 diseases and injuries, 1990-2015:a systematic analysis for the global burden of disease study 2015. Lancet2016;388(10053):1545-1602. https://doi.org/https://doi. org/10.1016/S0140-6736(16)31678-6.

11. Wang JH, Zhai YM, Zhang DF. Meta analysis on the relationship between working time and risk of depression among the adults. Prev Med Tribune2017;23(8):587-590. https://doi.org/https://doi.org/10.16406/j.pmt. issn.1672-9153.2017.08.008.

12. Nakata A. Long working hours, job satisfaction, and depressive symptoms: a community-based cross-sectional study among Japanese employees in small- and medium-scale businesses. Oncotarget.2017;8(32):53041-53052. https://doi.org/https://doi.org/10.18632/oncotarget.18084.

13. Tsuno K, Kawachi I, Inoue A, Nakai S, Tanigaki T, Nagatomi H, et al. Long working hours and depressive symptoms: moderating effects of gender, socioeconomic status, and job resources. Int Arch Occup Environ Health2019;92(5):661-672. https://doi.org/https://doi.org/10.1007/s00420-01 9-01401-y.

14. Weston G, Zilanawala A, Webb E, Carvalho LA, McMunn A. Long work hours, weekend working and depressive symptoms in men and women: findings from a UK population-based study. J Epidemiol Community Health2019;73(5):465-474. https://doi.org/https://doi.org/10.1136/jech-201 8-211309

15. Virtanen $M$, Jokela M, Madsen IEH, Magnusson Hanson LL, Lallukka T, Nyberg S, et al. Long working hours and depressive symptoms: systematic review and meta-analysis of published studies and unpublished individual participant data. Scand J Work Environ Health2018:44(3):239-250. http://doi. org/https://doi.org/10.5271/sjweh.3712.

16. Yoon Y, Ryu J, Kim H, Kang CW, Jung-Choi K. Working hours and depressive symptoms: the role of job stress factors. Ann Occup Environ Med 2018;30: 46:1-9. http://doi.org/https://doi.org/10.1186/s40557-018-0257-5.

17. Siegrist J. Adverse health effects of high-effort/low-reward conditions. J Occup Health Psychol 1996;1(1):27-41. http://doi.org/https://doi.org/10.103 7//1076-8998.1.1.27

18. Geurts SA, Sonnentag S. Recovery as an explanatory mechanism in the relation between acute stress reactions and chronic health impairment. Scand J Work Environ Health 2006;32(6):482-492. http://doi.org/https://doi. org/10.5271/sjweh. 1053 .

19. Caruso CC, Bushnell T, Eggerth D, Heitmann A, Kojola B, Newman K, Rosa RR, Sauter SL, Vila B Long working hours, safety, and health: toward a national research agenda. Am J Ind Med 2006:49(11):930-942. http://doi. org/https://doi.org/10.1002/ajim.20373.

20. Varma A, Marott JL, Stoltenberg CDG, Wieclaw J, Kolstad HA, Bonde JPE. With long hours of work, might depression then lurk? A nationwide prospective follow-up study among Danish senior medical consultants. Scand J Work Environ Health, 2012;38(5):418-426. http://doi.org/https://doi. org/10.5271/sjweh.3268.

21. Nakata A. Work hours, sleep sufficiency, and prevalence of depression among fulltime employees: a community-based crosssectional study. J Clin Psychiatry2011; 72(5):605-614. http//doi.org/https://doi.org/10.4088/JCP.10m06397gry.

22. Sunderajan P, Gaynes BN, Wisniewski SR, Miyahara S, Fava M, Akingbala F, DeVeaugh-Geiss J, Rush AJ, Trivedi MH Insomnia in patients with depression: a STAR*D report. CNS Spectr2010;15(6):394-404. https://doi.org/ https://doi.org/10.1017/S1092852900029266.

23. Baglioni C, Battagliese G, Feige B, Spiegelhalder K, Nissen C, Voderholzer U, Lombardo C, Riemann D Insomnia as a predictor of 
depression: a meta-analytic evaluation of longitudinal epidemiological studies. J Affect Disord2011;135(1-3):10-19. https://doi.org/10.1016/j.jad. 2011.01.011.

24. Xiang YT, Ma X, Cai ZJ, Li SR, Xiang YQ, Guo HL, Hou YZ, Li ZB, Li ZJ, Tao YF, Dang WM, Wu XM, Deng J, Lai KYC, Ungvari GS The prevalence of insomnia, its sociodemographic and clinical correlates, and treatment in rural and urban regions of Beijing, China: a general population-based survey. Sleep.2008;31(12):1655-1662. https://doi.org/https://doi.org/10.1093/ sleep/31.12.1655

25. Iresearch. Sleep report of Chinese Internet company employees, 2016. http://report.iresearch.cn/report/201603/2552.shtml. Accessed 18 Aug 2020.

26. Wang W, Bian Q, Zhao Y, Li X, Wang WW, Du J, et al. Reliability and validity of the Chinese version of the patient health questionnaire (PHQ-9) in the general population. Gen Hosp Psychiatry2014;36(5):539-544. https://doi.org/ https://doi.org/10.1016/j.genhosppsych.2014.05.021.

27. Kroenke K, Spitzer RL. The PHQ-9: A new depression diagnostic and severity measure. US: SLACK. 2002;32:509-515. https://doi.org/https://doi.org/10.392 8/0048-5713-20020901-06.

28. National People's Congress. Labor Law of the People's Republic of China. 1994. http://www.gov.cn/banshi/2005-08/31/content_74649.htm. Accessed 18 Aug 2020.

29. State Council of the People's Republic of China. The regulations of the State Council on the working hours of workers. 1995. http:/www.mohrss.gov.cn/ SYrlzyhshbzb/zcfg/flfg/xzfg/201604/t20160412_237909.html. Accessed 18 Aug 2020.

30. Nakata A, Haratani T, Takahashi M, Kawakami N, Arito H, Kobayashi F, Araki S Job stress, social support, and prevalence of insomnia in a population of Japanese daytime workers. Soc Sci Med2004;59(8):1719-1730. https://doi. org/10.1016/j.socscimed.2004.02.002.

31. Lichstein KL, Durrencea HH, Taylor DJ, Bush AJ, Riedel BW. Quantitative criteria for insomnia. 2003;4(41):427-445. http://doi.org/https://doi.org/10.1 016/s0005-7967(02)00023-2.

32. Roth T. Insomnia: definition, prevalence, etiology, and consequences. J Clin Sleep Med. 2007;3(5 Suppl):s7-10

33. Saleh ZT, Lennie TA, Mudd-Martin G, Bailey AL, Novak MJ, Biddle M, Khalil AA, Darawad M, Moser DK Decreasing sedentary behavior by 30 minutes per day reduces cardiovascular disease risk factors in rural Americans. Heart Lung2015;44(5):382-386. https://doi.org/https://doi.org/10.1016/j.hrtlng.2015. 06.008 .

34. Bannai A, Tamakoshi A. The association between long working hours and health: a systematic review of epidemiological evidence. Scand J Work Environ Health2014;40(1):5-18. http://doi.org/https://doi.org/10.5271/ sjweh.3388.

35. Watanabe K, Imamura K, Kawakami N. Working hours and the onset of depressive disorder: a systematic review and meta-analysis. Occup Environ Med 2016;73(12):877-884. http://doi.org/https://doi.org/10.1136/oemed-201 6-103845.

36. Afonso P, Fonseca M, Pires J F. Impact of working hours on sleep and mental health. Occup Med (Lond). 2017;67(5):377-382. https://doi.org/ https://doi.org/10.1093/occmed/kqx054.

37. Kleppa E, Sanne B, Tell GS. Working overtime is associated with anxiety and depression: the Hordaland health study. J Occup Environ Med2008;50(6): 658-666. https://doi.org/https://doi.org/10.1097/JOM.0b013e3181734330.

38. Meijman TF, Mulder G. Psychological aspects of workload. Hove, England: Psychology Press/Erlbaum (UK) Taylor \& Francis; 1998. p. 5-33.

39. Hülsheger UR, Feinholdt A, Nübold A. A low-dose mindfulness intervention and recovery from work: effects on psychological detachment, sleep quality, and sleep duration. United Kingdom: Wiley-Blackwell Publishing Ltd 2015; 88:464-489. https://doi.org/https://doi.org/10.1111/joop.12115, 3.

40. Mazloum A, Kumashiro M, Izumi H, Higuchi Y. Quantitative overload: a source of stress in data-entry VDT work induced by time pressure and work difficulty. Ind Health2008;46(3):269-280. https://doi.org/https://doi.org/10.24 86/indhealth.46.269.

41. Nishikitani M, Nakao M, Karita K, Nomura K, Yano E. Influence of overtime work, sleep duration, and perceived job characteristics on the physical and mental status of software engineers. Ind Health2005;43(4):623-629. https:// doi.org/https://doi.org/10.2486/indhealth.43.623.

42. Proctor SP, White RF, Robins TG, Echeverria D, Rocskay AZ. Effect of overtime work on cognitive function in automotive workers. Scand J Work Environ Health1996;22(2):124-132. https://doi.org/https://doi.org/10.5271/ sjweh.120.
43. Tyssen R, Vaglum P, Gronvold NT, Ekeberg O. The impact of job stress and working conditions on mental health problems among junior house officers. A nationwide Norwegian prospective cohort study. Med Educ2000; 34(5):374-384. https://doi.org/https://doi.org/10.1046/j.1365-2923.2000.0054 $0 . x$.

44. Staner L. Comorbidity of insomnia and depression. Sleep Med Rev2010; 14(1):35-46. https://doi.org/https://doi.org/10.1016/j.smrv.2009.09.003.

45. Vandekerckhove M, Cluydts R. The emotional brain and sleep: an intimate relationship. Sleep Med Rev2010;14(4):219-226. https://doi.org/https://doi. org/10.1016/j.smrv.2010.01.002.

46. Pagnin D, de Queiroz V, Carvalho YT, Dutra ASS, Amaral MB, Queiroz TT. The relation between burnout and sleep disorders in medical students. Acad Psychiatry2014;38(4):438-444. https://doi.org/https://doi.org/10.1007/s40596014-0093-z.

\section{Publisher's Note}

Springer Nature remains neutral with regard to jurisdictional claims in published maps and institutional affiliations.
Ready to submit your research? Choose BMC and benefit from:

- fast, convenient online submission

- thorough peer review by experienced researchers in your field

- rapid publication on acceptance

- support for research data, including large and complex data types

- gold Open Access which fosters wider collaboration and increased citations

- maximum visibility for your research: over $100 \mathrm{M}$ website views per year

At BMC, research is always in progress.

Learn more biomedcentral.com/submissions 